Two examples will show the working of the method.

To find $\sin 36^{\circ}$, we have $p=6, q \div 4$.

$$
\begin{aligned}
\cdot 6(\cdot 6428) & =\cdot 38568 \\
.4(\cdot 5000) & =\cdot 20000 \\
.064(\cdot 0196) & =.00126 \\
.056(.0152) & =\frac{.00085}{.58779} \text { say } .5878 .
\end{aligned}
$$

To find $\sin 72^{\circ} 30^{\prime}$, we have $p=t, q=z^{3}$, giving $-\tau_{2}^{\circ}$, and $-{ }_{1} \frac{7}{2} g$ as the coefficients of $u_{1}^{\prime \prime} u_{0}^{\prime \prime}$. Hence we obtain

$$
\begin{aligned}
& \text { f }(.9848)=\cdot 2462
\end{aligned}
$$

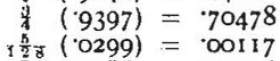

$$
\begin{aligned}
& \times 28(.0286)=00156 \\
& \text { '95371 say } 9537 .
\end{aligned}
$$

Both these results are correct to the last figure.

The formula of interpolation here employed (which can be carried to higher terms when necessary) seems to be new. I gave it to Section $\mathrm{A}$ at the last meeting of the British Associa tion, and have illustrated its use more fully in the Journal of the Institute of Actuaries for last month (January). It will also appear with other kindred matter in the next number of the Quarterly Tournal of Mathematics. J. I. Everetr.

\section{Frost Fronds.}

ON the morning of January 29, as I was walking from this place down Haverstock Hill into I,ondon, about 9.30, my attention was attracted by the "frost fronds" on the Hlags of the footpath. I see instances not unfrequently, and have called attention to one variety, where they form divergent groups, like the sticks of a partly opened fan, resembling the well-known crystals of actinolite obtained on the southern side of the St. (rothard Pass (see Proc. R'oy. Soc. lxiii. p. 217, and Quart. Journ. Geol. Soc. liv. p. 368); but those now mentioned were characterised by unusual delicacy and grace. They formed groups, often half a yard in diameter, composed of frond-like radiating tufts, made up of thin stems or acicular crystals (often some four inches long and about the thickness of a bodkin) beautifully curved: this almost invariable bending of the "blades" being the most marked characteristic. They resem. bled very delicate seaweeds, dried and displayed on a card as an ornamental group. In descending the hill I observed that the crystals became a little coarser and more like those already mentioned. Also that sometimes clots of frozen mud appeared near the junction of the fronds, as if a trefoil or quatrefoil leaf had been placed there to hide it. I attribute the unusual delicacy of the fronds to the fact that the previous evening had been showery, and so the pavement had been cleaned of all but the very finest mud, after which had come a drying wind and a frost. Thus crystallisation probably occurred in a very thin film of slightly turbid water and on a fairly smooth surface, so that opposition to it was comparatively slight and the circumstances approached more nearly to the crystallisation of water on glass. I could not linger to make a minute study as I was pressed for time, but write this in the hope that some one who can take photographs (which I cannot) will collect examples of "frost fronds," for I believe they would be helpful in interpreting crystal building in rock masses. T. G. BoNNEY.

23 Denning Road, Hampstead, N.W., January $3 \mathrm{I}$.

\section{The Total Solar Eclipse of May I7-18.}

THE Board of the Koninklijke Natuurkundige Vereeniging at Batavia has applied to the Government in regard to the custom duties to be levied from scientific observing parties who may visit the Dutch colonies for the observation of the total solar eclipse on May 17-18. The following reply has been received.

No duties will be levied on goods not exempted by the tariff, but destined to be re-exported after the observation of the eclipse has been concluded; observing parties may obtain further information from the chief Custom House officer at the port of arrival.

$$
\text { NO. } 1632 \text {, vOL. } 63]
$$

Besides all possible facilities in having their goods imported, exemption from search will be afforded to scientific expeditions. We feel much pleasure in bringing the above under the notice of intending observing parties. January $\mathrm{I}$. J. J. A. MULLER. (President of the Kon. Natuurk. Ver., Batavia).

The Museum of the Institute of Jamaica.

Is connection with your items regarding the possible return of I)r. J. E. Duerden, curator of the Jamaica Institute Museum, to England, may one who has spent two summers in Jamaica engaged in zoological research, and who has enjoyed the hospitality of Dr. Duerden and other men of science there, be permitted to say a word as to the causes which have led to the present unfortunate situation? There are two such principal causes, I believe, not closely related, but in this case working together toward a common end. The most important of these is local jealousy, against which Dr. Duerden has had to contend constantly ever since his arrival at the island. At the time he was appointed, a large and influential element among the supporters of the Institute desired the appointment of a young Jamaican, who had received some training in England, and who was doubtless well qualified for the duties of the position. His failure to secure the office was a bitter disappointment, not only to himself, but to his friends, and Dr. Duerden entered on his duties with an unfortunately large number of hostile critics, watching for opportunities to find fault. It is very possible-in fact, since Dr. Duerden is human, it is highly probable- that opportunities for criticism arose, and possibly the criticisms have not always been met in the wisest possible spirit. But it is clear to me, and I think I can speak for all the Johns Hopkins men who were in Jamaica, that if Dr. Duerden's local critics had been as anxious to help him and build up the museum as they were to find fault, there would be no trouble at the present time. I do not mean to say that Dr. Duerden has been entirely blameless, but I feel sure that his responsibility for the trouble is very much less than that which rests on his critics. The fact that Dr. Duerden is a trained investigator, and has given a large share of his time to research work, has given opportunity for criticism from those who believe the curator ought to devote bis time to adding new specimens to the exhibition collection and labelling them all properly.

The other cause of the proposed retrenchment is one which appeals to me strongly, and must, I think, to all unprejudiced persons who know the facts. The colonial expenses are greater than the income, and the debt is already heavy. A very large proportion of the expense account is made up of salaries paid the English civil officials, from Governor down. The Governor receives a salary of $6000 \%$, besides two residences and the usual perquisites of his position. This salary is grotesquely enormous under the circumstances. Jamaica is not only a delightful place to live in, a veritable paradise in many respects, but it is a very cheap place as well. I should estimate, from my slight experience there, that living expenses are about three-fifths of what they are in the eastern United States. Most Englishnen in Jamaica do not realise or believe this, for they still cling to English food and English customs. Now the colony, a few years ago, attempted to secure the reduction of the salaries of colonial officials, and suggested a saving of $1000 /$. on the Governor's salary, but the proposition was promptly ended by that official's veto, which is absolute. So every attempt to decrease expenses by decreasing salaries has failed, and now retrenchment has to come somewhere, and since a zoologist is of small account, especially one who has some powerful enemies, Dr. Duerden is to be sent back to England. If this event actually takes place the blame will rest, not on Jamaica, but on England. There is little chance for the advance of scientific research in that island so long as it is looked on by English politicians as a possession to be exploited for the benefit of the office-holders.

I trust it is not yet too late for the scientific men of England to make such an emphatic protest to the proper authorities that the Board of Governors of the Jamaica Institute may be compelled to retain Dr. Duerden as curator of the museum, if he can be persuaded to stay, and if not, to secure some equally competent and well-trained investigator to fill his place.

Olivet College, Michigan, January 15. 